\title{
ANALISIS DAYA SAING EKSPOR KOMODITAS KARET ALAM PROVINSI JAWA TENGAH
}

\author{
Ismiati Marfu'ah Rochmat*, Darsono dan Erlyna Wida Riptanti \\ Program Studi Agribisnis Fakultas Pertanian, Universitas Sebelas Maret \\ *Corresponding author: ismiatimarfuah@student.uns.ac.id
}

\begin{abstract}
This research aims to determine how the competitiveness of natural rubber export of Central Java Province in terms of its comparative advantages and competitive advantages. The basic method of research is analytical descriptive. The research location is Central Java Province, where the area is potentially in manages natural rubber to make the superior plantation commodities and has been exported continuously. The data used in this research are primary and secondary data. The data analysis used is XCI (Export Competitiveness Index) and RCA (Revealed Comparative Advantage) analysis. The results show: The competitiveness of natural rubber export of Central Java Province observed from the competitive advantage by using XCI (Export Competitiveness index) analysis, shows that the average XCI value of natural rubber Central Java Province during 2001 until 2015 is more than one that is 1,08 and indicates that the natural rubber commodity of Central Java Province has an increasing competitive trend in the international market. The competitiveness of natural rubber export of Central Java Province observed from comparative advantage by using RCA (Revealed Comparative Advantage) analysis shows that the average value of RCA of natural rubber of Central Java Province during 2001 to 2015 is more than one that is 6,82 and indicates that natural rubber commodities have a high comparative advantage (above the world average).
\end{abstract}

Keywords: Comparative advantage; Competitive advantage; Competitiveness; Export; Natural rubber

Cite this as: Rochmat, I., Darsono, D., \& Riptanti, E. 2017. Analisis Daya Saing Ekspor Komoditas Karet Alam Provinsi Jawa Tengah. Caraka Tani: Journal of Sustainable Agriculture. 32(2), 95-100. doi: http://dx.doi.org/10.20961/carakatani.v32i2.13670

\section{PENDAHULUAN}

Peradaban dunia yang terus berkembang pesat khususnya dalam bidang ekonomi, membuat semua negara harus mengikuti arus perekonomian global. Perdagangan internasional merupakan salah satu cara dalam menghadapi perekonomian global yang sedang terjadi. Indonesia sudah lama melakukan perdagangan internasional, khususnya dalam ekspor berbagai produk ke luar negeri. Terdapat dua jenis sumberdaya alam di Indonesia yaitu sumberdaya migas dan non migas. Sumberdaya non migas merupakan produk yang paling banyak diekspor oleh Indonesia.

Ekspor non migas sub sektor perkebunan dari sektor pertanian menurut data BPS (2016) pada tahun 2015 mampu berkontribusi sebesar 95,96\% dari seluruh sektor pertanian, sehingga menjadi penopang perekonomian nasional yang cukup besar. Komoditas dari sub sektor perkebunan yang menjadi unggulan salah satunya yaitu karet.
Jenis tanah wilayah Indonesia yang subur dan iklim yang cocok untuk ditanami karet membuat hasil perkebunan karet menjadi sektor unggulan di Indonesia. Indonesia merupakan negara produsen karet alam terbesar di dunia dibandingkan Thailand, Vietnam dan Malaysia (International Trade Statistics, 2016).

Areal perkebunan karet alam di Indonesia tersebar luas pada 27 provinsi dan salah satunya ada di Provinsi Jawa Tengah. Menurut Statistik Karet Indonesia (2016) pada tahun 2015, Provinsi Jawa Tengah memiliki luas areal sebesar 36.590 hektar atau sekitar 1,01\% dari seluruh areal perkebunan di Indonesia dan produksi karet sebanyak 36.038 ton atau sekitar $1,16 \%$ dari seluruh produksi karet alam di Indonesia. Meskipun kecil dominasi luas areal perkebunan dan produksi karet alamnya, namun karet alam Provinsi Jawa Tengah merupakan hasil perkebunan yang paling banyak diekspor dibanding dengan hasil perkebunan lainnya 
(Tabel 1). Ekspor karet alam diolah menjadi lembaran karet yang disebut Ribbed Smoked Sheet atau biasa disingkat RSS.

Tanaman karet alam di Jawa Tengah diusahakan oleh perkebunan rakyat, perkebunan besar negara dan perkebunan besar swasta.
Namun yang berperan besar dalam mengusahakannya adalah perkebunan besar negara (PTPN IX) dengan luas areal 59,24\% dari keseluruhan sedangkan perkebunan rakyat sebesar 26,08\% serta swasta hanya sekitar 14,69\% (Statistik Perkebunan Jawa Tengah 2016).

Tabel 1. Volume Ekspor Komoditas Perkebunan Provinsi Jawa Tengah tahun 2011-2015

\begin{tabular}{lrrrrr}
\hline \multicolumn{1}{c}{ Jenis } & \multicolumn{5}{c}{ Volume Ekspor (Ton) } \\
\cline { 2 - 6 } \multicolumn{1}{c}{ Komoditi } & \multicolumn{1}{c}{ 2011 } & \multicolumn{1}{c}{ 1612 } & \multicolumn{1}{c}{ 1013 } & \multicolumn{1}{c}{2015} \\
\hline Karet Alam & $16.543,66$ & $13.109,96$ & $14.178,06$ & $16.742,21$ & $20.045,22$ \\
Kopi & $10.447,17$ & $6.259,94$ & $7.831,98$ & $6.905,66$ & $7.092,00$ \\
Tembakau & $1.250,46$ & 864,17 & 786,49 & 695,03 & 779,64 \\
Cengkeh & $1.101,74$ & 614 & $1.049,07$ & 933,35 & $1.367,78$ \\
Minyak Kelapa & $5.315,91$ & $10.391,55$ & $3.396,24$ & $5.926,83$ & $9.886,53$ \\
Minyak atsiri & $2.119,39$ & $2.071,43$ & $2.256,84$ & $2.244,58$ & $2.188,58$ \\
Teh & 439,53 & 262,1 & 390,08 & 209,03 & 152,18 \\
Biji Pala & 992,78 & $1 . .240,87$ & 882,52 & 994,75 & 722,18 \\
\hline
\end{tabular}

Sumber: Dinas Perkebunan Provinsi Jawa Tengah, 2016

Pertumbuhan permintaan ekspor karet alam dapat dilihat dari perkembangan konsumsi karet alam yang dilakukan oleh negara-negara di dunia. Selama tahun 2011 hingga 2015 konsumsi karet alam di dunia mengalami kecenderungan yang meningkat (IRSG, 2016). Peningkatan permintaan tersebut terjadi karena dipengaruhi oleh konsumen dan harga. Konsumen akan membeli lebih banyak karet alam apabila harga karet dianggap murah atau dapat dijangkau begitupun sebaliknya. Oleh sebab itu, permintaan tergantung pada daya beli konsumen. Permintaan karet alam yang semakin meningkat ini membuat negara-negara pengekspor karet alam saling bersaing untuk memenuhi permintaan tersebut. Apalagi saat ini Indonesia telah memasuki Masyarakat Ekonomi Asean dimana terjadi pemberlakuan pasar bebas yang memungkinkan satu negara menjual barang dan jasa dengan mudah ke negara-negara lain di seluruh Asia Tenggara. Terbukanya pasar membuat persaingan yang terjadi terhadap ekspor komoditas karet alam menjadi semakin ketat. Oleh karena itu sangat penting sebagai informasi awal untuk menjelaskan kondisi daya saing komoditas karet alam Provinsi Jawa Tengah di pasar ekspor.

Berdasarkan uraian diatas maka dapat dirumuskan permasalahan bagaimana daya saing ekspor komoditas karet alam Provinsi Jawa Tengah ditinjau dari keunggulan komparatif dan keunggulan kompetitifnya.

\section{METODE PENELITIAN}

Metode dasar penelitian yang digunakan adalah metode deskriptif. Metode penentuan lokasi penelitian dilakukan secara purposive (sengaja). Jenis dan sumber data yang digunakan adalah data primer dengan wawancara dan data sekunder berupa data time series dari tahun 2001 hingga tahun 2015 yang peroleh dari instansi terkait. Teknik pengumpulan data dengan teknik pencatatan, teknik observasi dan teknik wawancara. Metode analisis data yang digunakan adalah metode analisis XCI (Export Competitiveness index) dan RCA (Revealed Comparative Advantage) yang dirumuskan sebagai berikut:

$$
X C I=\frac{\left(X^{i} a / X^{w} a\right) t}{\left(X^{i} a / X^{w} a\right) t-1}
$$

Keterangan:

$\mathrm{XCI}=$ Indikator daya saing (keunggulan kompetitif)

$\mathrm{X}^{\mathrm{i}} \mathrm{a}=$ Nilai ekspor karet alam dari suatu wilayah (US\$)

$\mathrm{X}^{\mathrm{w}} \mathrm{a}=$ Nilai ekspor karet alam dunia (US\$)

$\mathrm{t}=$ Periode berjalan

$\mathrm{t}^{-}{ }_{1} \quad=$ Periode sebelumnya

$\mathrm{i} \quad=$ wilayah (Jawa Tengah)

a $\quad$ komoditas (karet alam)

$\mathrm{w}=$ dunia 
Apabila nilai XCI suatu komoditas lebih besar dari satu, berarti komoditas tersebut menghadapi trend daya saing yang meningkat. Sebaliknya, apabila nilai XCI lebih kecil dari satu, maka komoditas tersebut menghadapi kemungkinan penurunan trend daya saing yang melemah (Amir, 2000).

$$
R C A=\frac{X_{i a} / X_{i t}}{X_{w a} / X_{w t}}
$$

Keterangan:

$$
\begin{aligned}
\mathrm{RCA}= & \text { Indikator daya saing (keunggulan } \\
& \text { komparatif) } \\
\mathrm{X}_{\mathrm{ia}}= & \text { Nilai ekspor karet alam dari } \\
& \text { suatu wilayah (US\$) } \\
\mathrm{X}_{\mathrm{it}}= & \text { Nilai ekspor total seluruh } \\
& \text { komoditas dari suatu wilayah (US\$) } \\
\mathrm{X}_{\mathrm{wa}}= & \text { Nilai ekspor karet alam dunia (US\$) } \\
\mathrm{X}_{\mathrm{wt}}= & \text { Nilai ekspor total seluruh } \\
& \text { komoditas dunia (US\$) } \\
\mathrm{i} \quad= & \text { wilayah (Jawa Tengah) } \\
\mathrm{a} \quad= & \text { komoditas (karet alam) } \\
\mathrm{W}= & \text { dunia } \\
\mathrm{t}= & \text { total seluruh komoditas ekspor }
\end{aligned}
$$

Nilai indeks RCA lebih besar dari satu berarti negara itu mempunyai keunggulan komparatif (diatas rata-rata dunia). Sebaliknya, lebih kecil dari satu berarti keunggulan komparatifnya rendah/dibawah rata-rata dunia (Tambunan, 2004).

\section{HASIL DAN PEMBAHASAN}

Karet alam Provinsi Jawa Tengah diekspor dalam bentuk bongkahan karet terdiri dari beberapa lembaran karet yang berasal dari getah karet alam yang telah mendapatkan proses pengasapan dengan baik sesuai standar mutu yang berlaku. Pengemasan dilakukan dengan menggunakan bandela yang berukuran $60 \times 48 \times 48$ $\mathrm{cm}$ dengan berat $113 \mathrm{~kg}$ dan harus tahan dari faktor luar. Produk olahan karet disortasi dan dikelompokkan menjadi beberapa kelas yaitu sebagai berikut: RSS 1, RSS 2, RSS 3, RSS 4, Cutting A, Cutting B, BRCR (Brown Crepe) 1X, BRCR 2X, BRCR 3X.

Getah karet alam yang berasal dari perkebunan Rakyat, perkebunan Swasta dan perkebunan Negara disalurkan ke pabrik lateks baik secara langsung ataupun melalui pegepul/KUD. Kemudian getah karet alam yang sudah berupa lateks disalurkan ke pemasok untuk diekspor maupun untuk dijual di dalam negeri melalui industri-industri barang olahan karet alam skala besar atau kecil dan umumnya bersifat langganan. Pemasaran lateks karet alam produk PTPN IX yang ditawarkan ke pasar ekspor dilakukan dengan sistem tender. Negara-negara pengimpor karet alam pada umumnya menggunakan karet alam sebagai bahan baku industri otomotif, kebutuhan rumah tangga, dan lain-lain (Widayanti, 2008).

\section{Analisis Tingkat Daya Saing Ekspor Karet Alam Provinsi Jawa Tengah dilihat dari Keunggulan Kompetitif}

Berdasarkan Tabel 2 rata-rata nilai XCI selama tahun 2001 hingga 2015 sebesar 1,08 dimana nilainya lebih besar dari satu yang mengindikasikan bahwa karet alam Jawa Tengah memiliki keunggulan kompetitif yang artinya memiliki trend daya saing yang meningkat di pasar internasional. Peningkatan trend daya saing ini bisa terjadi karena selama tahun 2001 hingga 2015 ada beberapa nilai XCI yang hasilnya tinggi sehingga apabila di rata-rata hasilnya akan tinggi juga. Karet alam Provinsi Jawa Tengah yang memiliki keunggulan kompetitif ini juga dapat dilihat dari harga ekspor karet alam yang bersaing dengan negara-negara produsen karet alam lainnya.

Tabel 2. Hasil Perhitungan XCI (Export Competitiveness index) Karet Alam Provinsi Jawa Tengah tahun 20012015

\begin{tabular}{cc}
\hline Tahun & Nilai RCA Karet Alam \\
\hline 2001 & - \\
2002 & 1,45 \\
2003 & 1,37 \\
2004 & 0,54 \\
2005 & 1,08 \\
2006 & 1,11 \\
2007 & 0,96 \\
2008 & 0,76 \\
2009 & 1,65 \\
2010 & 0,61 \\
2011 & 1,21 \\
2012 & 0,67 \\
2013 & 1,28 \\
2014 & 1,30 \\
2015 & 1,21 \\
\hline Rata-rata & $\mathbf{1 , 0 8}$
\end{tabular}


Menurut data realisasi penjualan karet alam pada tahun 2015 harga ekspor karet alam Provinsi Jawa Tengah mencapai 1,524 US\$/kg sedangkan di negara-negara produsen karet alam terbesar di dunia, berdasarkan data International Trade Statistics negara Thailand harga ekspor karet alamnya sebesar 1,362 US\$/kg, negara Vietnam sebesar 1,350 US\$/kg dan Malaysia sebesar 1,464 US $\$ / \mathrm{kg}$. Berdasarkan data-data tersebut terlihat bahwa harga ekspor karet alam Provinsi Jawa Tengah lebih tinggi dibandingkan negara-negara produsen terbesar karet alam di dunia menandakan bahwa Provinsi Jawa Tengah kompetitif dalam harga ekspor karet alam.

Secara keseluruhan selama tahun 2001 hingga 2015 nilai XCI karet alam Jawa Tengah mengalami fluktuasi. Tahun 2009 menjadi tahun dimana karet alam Jawa Tengah memiliki nilai XCI paling tinggi yaitu sebesar 1,65. Nilai tersebut berada diatas nilai satu yang mengindikasikan bahwa karet alam Jawa Tengah memiliki keunggulan kompetitif dilihat dari trend daya saing yang meningkat.

Padahal di tahun 2009 nilai ekspor karet alam Jawa Tengah dan dunia mengalami penurunan, namun penurunan ekstrim terjadi pada ekspor karet alam dunia sehingga menjadikan karet alam Jawa Tengah lebih bersaing. Penurunan nilai ekspor karet alam Jawa Tengah sebesar 1,35\% sedangkan penurunan nilai ekspor karet alam dunia mencapai 40,24\%. Penurunan nilai ekspor karet alam ini bisa terjadi karena dipengaruhi oleh harga karet alam yang menurun dari 2.493 US\$/ton menjadi 1.595 US\$/ton. Penurunan ekspor karet alam dunia dapat terjadi karena adanya krisis global yang melanda pada kuartal ketiga tahun 2008 yang membawa dampak terhadap kuantitas dan nilai ekspor karet alam dunia yang menurun di tahun 2009 (Ratnawati, 2011).

Namun, dampak dari krisis global dunia tidak terlalu berdampak pada penurunan ekstrim nilai ekspor karet alam Jawa Tengah. Hal itu disebabkan adanya perbaikan kinerja ekspor karet alam melalui kebijakan pemerintah. Kebijakan yang mengatur sektor karet nasional tercakup dalam Permendag No. 10/M-DAG/PER/4/2008 tentang Ketentuan Karet Alam Spesifikasi Teknis Indonesia (SIR) yang Diperdagangkan ke Luar Negeri dan Permendag No. 53/MDAG/PER/10/2009 tentang Pengawasan Mutu Bahan Olah Komoditi Ekspor Standard Indonesian Rubber yang Diperdagangkan.
Permasalahan ekspor karet alam sebelumnya terletak pada standar mutu yang masih rendah dibandingkan dengan produsen negara lain. Selain itu, adanya hubungan dagang yang terjamin antara ASEAN dan Tiongkok melalui ACFTA yang dimulai dari tahun 2004 memberikan dampak yang baik terhadap ekspor karet alam di Indonesia termasuk Jawa Tengah. Adanya kebijakan yang dibuat oleh IRCL (International Rubber Consortium Limited) yaitu lembaga/organisasi yang dibentuk oleh tiga negara produsen utama karet alam yakni Thailand, Indonesia dan Malaysia, dalam mempertahankan kestabilan harga turut berpengaruh terhadap penguatan stabilitas perdagangan karet alam di pasar internasional yang berdampak terhadap karet alam Jawa Tengah yang lebih kompetitif.

Menurut Leamer dan Stern (1970), faktor penyebab lebih tingginya pertumbuhan ekspor tersebut antara lain adalah suatu wilayah pengekspor memfokuskan ekspornya pada suatu produk atau kelompok produk tertentu yang pertumbuhan permintaan ekspornya tinggi, ekspor tersebut lebih ditujukan ke negara-negara yang pertumbuhan ekspornya tinggi dan negara pengekspor yang bersangkutan mampu dalam bersaing dengan negara-negara pesaingnya. Berdasarkan dari penyebab tersebut, karet alam Jawa Tengah memiliki pertumbuhan ekspor yang tinggi karena komoditas karet alam memiliki pertumbuhan permintaan ekspor yang cenderung meningkat. Permintaan ekspor karet alam bisa dilihat dari konsumsi karet alam dunia selama tahun 2011 hingga 2015 mengalami pertumbuhan sebesar 3,9\% (IRSG, 2016) dan ekspor karet alam Jawa Tengah ditujukan ke negara-negara yang pertumbuhan permintaannya tinggi seperti Taiwan yang rata-rata mengimpor 2.911 ton per tahun dan Tiongkok sebesar 2.606 ton/tahun (Statistik Ekspor Jawa Tengah, 2016).

Tahun 2004 karet alam Jawa Tengah memiliki nilai XCI paling kecil yaitu sebesar 0,54 dimana nilainya berada dibawah satu yang mengindikasikan karet alam tidak memiliki keunggulan kompetitif dilihat dari trend daya saing yang melemah. Melemahnya trend daya saing ini disebabkan oleh adanya penurunan pertumbuhan nilai ekspor karet alam Jawa Tengah sebesar 28,82\% sedangkan pertumbuhan nilai ekspor karet alam dunia mengalami peningkatan sebesar 32,7\%. Penurunan nilai ekspor karet alam Jawa Tengah disebabkan oleh menurunnya 
volume ekspor karet alam dari tahun sebelumnya, hal tersebut terjadi karena kualitas ekspor karet alam Jawa Tengah yang kurang memenuhi standar mutu ekspor (Setyo, 2012).

Tingkat Daya Saing Ekspor Karet Alam Provinsi Jawa Tengah dilihat dari Keunggulan Komparatif

Berdasarkan Tabel 3, diketahui bahwa nilai RCA karet alam mengalami fluktuasi setiap tahunnya. Selama tahun 2001 hingga 2015 nilai RCA berada diatas angka satu dengan rata-rata nilai RCA sebesar 6,82 yang mengindikasikan bahwa karet alam Jawa Tengah memiliki keunggulan komparatif yang tinggi (berada diatas rata-rata dunia). Selama ini ekspor Indonesia mengandalkan faktor-faktor keunggulan komparatif sebagai penentu utama daya saingnya, terutama daya saing harga, seperti upah buruh yang murah dan sumberdaya alam berlimpah sehinga biaya pengadaan menjadi murah (Widyantari, 2013).

Tabel 3. Hasil Perhitungan RCA (Revealed Comparative Advantage) Karet Alam Provinsi Jawa Tengah Tahun 2001-2015

\begin{tabular}{cc}
\hline Tahun & Nilai RCA Karet Alam \\
\hline 2001 & 4,73 \\
2002 & 7,25 \\
2003 & 10,58 \\
2004 & 6,32 \\
2005 & 6,82 \\
2006 & 7,46 \\
2007 & 7,38 \\
2008 & 6,85 \\
2009 & 9,38 \\
2010 & 5,55 \\
2011 & 6,64 \\
2012 & 4,59 \\
2013 & 5,25 \\
2014 & 6,43 \\
2015 & 7,12 \\
\hline Rata-rata & $\mathbf{6 , 8 2}$ \\
\hline
\end{tabular}

Tahun 2012 karet alam Jawa Tengah memiliki nilai RCA paling rendah yaitu sebesar 4,59 dimana nilainya menurun dari tahun sebelumnya, namun tetap berada di atas nilai satu. Penurunan nilai RCA disebabkan oleh pangsa ekspor karet alam Jawa Tengah ke total ekspor Jawa Tengah pada tahun 2012 turun cukup jauh menjadi $0,91 \%$ bila dibandingkan dengan tahun 2011 yang dapat mencapai $1,68 \%$, sedangkan pangsa ekspor karet alam dunia ke total ekspor dunia pada tahun 2012 juga mengalami penurunan menjadi $0,19 \%$, namun tidak menurun terlalu jauh bila dibandingkan dengan tahun 2011 yang mencapai $0,25 \%$. Alasan turunnya pangsa ekspor karet alam Jawa Tengah ke total ekspor Jawa Tengah pada tahun 2012 adalah meningkatnya pangsa beberapa komoditas ekspor lainnya di Jawa Tengah.

Tahun 2003 karet alam Jawa Tengah memiliki nilai RCA paling tinggi yaitu sebesar 10,58 dimana nilainya meningkat dari tahun sebelumnya dan berada diatas satu yang mengindikasikan bahwa karet alam memiliki keunggulan komparatif yang tinggi (berada diatas rata-rata dunia). Hal tersebut disebabkan oleh pangsa ekspor karet alam Jawa Tengah ke total ekspor Jawa Tengah pada tahun 2003 naik cukup tinggi menjadi $0,93 \%$ bila dibandingkan dengan tahun 2002 yang hanya mencapai $0,49 \%$, sedangkan pangsa ekspor karet alam dunia ke total ekspor dunia pada tahun 2003 juga mengalami peningkatan menjadi $0,08 \%$, namun tidak meningkat cukup tinggi bila dibandingkan dengan tahun 2002 yang mencapai $0,06 \%$. Peningkatan pangsa ekspor karet alam Jawa Tengah ke total ekspor Jawa Tengah pada tahun 2002 adalah adanya peningkatan volume ekspor dari tahun sebelumnya sebesar 9.152 Ton meningkat menjadi 14.707 Ton. Volume ekspor yang meningkat tersebut didukung oleh produksi dan harga karet alam yang meningkat pula. Produksi karet alam tahun 2001 sebesar 23.220 Ton dengan harga $0,56 \mathrm{US} \$ / \mathrm{Kg}$ dan tahun 2002 meningkat produksi menjadi 24.019 Ton dengan harga 0,69 US $\$ / K g$ (Dinas Perkebunan Provinsi Jawa Tengah, 2016).

\section{KESIMPULAN DAN SARAN}

\section{Kesimpulan}

Daya saing ekspor karet alam Provinsi Jawa Tengah yang ditinjau dari keunggulan kompetitif dengan menggunakan analisis XCI (Export Competitiveness index), menunjukkan bahwa rata-rata nilai XCI karet alam Provinsi Jawa Tengah selama tahun 2001 hingga 2015 lebih dari satu yaitu sebesar 1,08 dan mengindikasikan bahwa komoditas karet alam Jawa Tengah memiliki trend daya saing yang meningkat di pasar internasional. Daya saing ekspor karet alam 
Provinsi Jawa Tengah yang ditinjau dari keunggulan komparatif dengan menggunakan analisis RCA (Revealed Comparative Advantage), menunjukkan bahwa rata-rata nilai RCA karet alam Provinsi Jawa Tengah selama tahun 2001 hingga 2015 lebih dari satu yaitu sebesar 6,82 dan mengindikasikan bahwa komoditas karet alam Jawa Tengah memiliki keunggulan komparatif yang tinggi (berada diatas rata-rata dunia).

\section{Saran}

Ditinjau dari keunggulan kompetitifnya, karet alam Provinsi Jawa Tengah dapat lebih ditingkatkan lagi dengan memperbaiki kualitas produk karet alam dengan cara pemberian perawatan secara intensif terhadap tanaman karet alam melalui pemberian pupuk, penyemprotan pestisida dan sebagainya, sehingga dapat menghasilkan getah karet alam yang berkualitas baik dan diterima oleh negara tujuan ekspor serta dapat meningkatkan harga ekspornya sehingga lebih mampu bersaing dengan negara-negara produsen karet alam alam di dunia. Ditinjau dari keunggulan komparatif, karet alam Provinsi Jawa Tengah dapat lebih ditingkatkan lagi dengan cara melakukan proses penyadapan getah karet alam dari pohonnya dengan perlakuan yang lebih baik dan lebih teliti lagi agar hasil yang diperoleh dapat menghasilkan produk olahan karet alam yang berkualitas baik.

\section{DAFTAR PUSTAKA}

Amir, M. 2000. Trade Liberalisation and Malaysian Export Competitiveness: Prospects, Problems, and Policy Impications. Departement of Economics. University of Newcastle. Australia.

BPS (Badan Pusat Statistik). 2016. Statistik Karet Indonesia 2015. Jakarta: Badan Pusat Statistik.

DISBUN (Dinas Perkebunan). 2016. Statistik Perkebunan Jawa Tengah 2015. Semarang: Dinas Perkebunan Provinsi Jawa.

International Rubber Study Group. 2016. Online: http://www.rubberstudy.com/statistics.aspx.

International Trade Statistics. 2016. List of the selected product 4001 Natural rubber, balata, gutta-percha etc http://trademap.org/Country_SelProduct_TS. aspx. Diakses 28 April 2016.
Leamer, \& Stern. 1970. Quantitative International Economics. Chicago: Aldine Publishing Company.

Ratnawati, E. 2011. Analisis Daya Saing Ekspor Karet Alam Indonesia di Pasar Internasional (Skripsi S1). Universitas Sebelas Maret Surakarta. Tidak dipublikasikan.

Setyo, P. 2012. Analisis Pertumbuhan Ekspor Karet Jawa Tengah. Program Stratasatu Universitas Sebelas Maret Surakarta. Tidak dipublikasikan.

Statistik Ekspor Jawa Tengah. 2016. Statistik Ekspor Jawa Tengah. Semarang: Badan Pusat Statistik Provinsi Jawa Tengah.

Tambunan, T. 2004. Globalisasi dan Perdagangan Internasional. Bogor: Penerbit Ghalia Indonesia.

Widayati, S. 2008. Neraca Perdagangan Komoditi Karet Antara Indonesia dengan Amerika Serikat. Jurnal Pertanian Mapeta. 10(3), 154163.

Widyantari, I. 2013. Daya Saing Ekspor Komoditas Kelapa Indonesia. SEPA. 10(1), 19-26. 